\title{
Perceived Effectiveness of Identified Methods and Techniques Teachers Adopt in Prose Literature Lessons in some Secondary Schools in Owerri
}

\author{
F. O. Ezeokoli \\ Department of Teacher Education, University of Ibadan, Nigeria \\ E-mail: drezeokoli@yahoo.com
}

Received: 28-05- 2016

Accepted: 25-07-2016

Published: 31-07-2016

doi:10.7575/aiac.ijels.v.4n.3p.54

URL: http://dx.doi.org/10.7575/aiac.ijels.v.4n.3p.54

\begin{abstract}
The study determined the methods adopted by teachers in prose literature-in-English classrooms, activities of teachers and students, teachers' perceived effectiveness of techniques used. It also examined the objectives of teaching prose literature that teachers should address and the extent teachers believe in student-identified difficulties of studying prose literature. The study adopted the descriptive survey research design. Purposive sampling technique was used to select 85 schools in Owerri metropolis and in each school, all literature teachers of senior secondary I and II were involved. In all, 246 literature teachers participated out of which 15 were purposively selected for observation. The two instruments were: Teachers' Questionnaire $(\mathrm{r}=0.87)$ and Classroom Observation Schedule $(\mathrm{r}=0.73)$. Data were analysed using frequency counts and percentages. Results revealed that teachers adopted lecture $(28.4 \%)$, reading $(10.9 \%)$ and discussion (7.3\%) methods. Teacher's activities during the lesson include: giving background information, summarizing, dictating notes, reading aloud and explaining and asking questions. The adopted techniques include: questioning, oral reading, silent reading and discussion. Teachers' perceived questioning as the most effective technique followed by debating and summarizing. Teachers identified development of students' critical faculties and analytical skills, literary appreciation and language skills to be of utmost concern. It was concluded that the methods adopted by teachers are not diverse enough to cater for the needs and backgrounds of students.
\end{abstract}

Keywords: Methods, Techniques, Perceived Effectiveness, Objectives, Literature-in-English

\section{Introduction}

One of the controversies that trailed the teaching of literature in a non-English speaking environment was whether it could be used to foster and complement the study of English or studied as literature per se. This is because students in a second language situation lack the linguistic competence to comprehend literary texts and foreign culture. Despite the unresolved consensus of purpose, literature was taught as a vehicle for promoting students' acquisition of language skills and cross-cultural studies. In this respect any of the literary genres is used to develop vocabulary and demonstrate grammatical principles treated in the class (Dietz, 1978). However, recent trends indicate that literature is studied primarily as a subject in English as a second language situation and as an adjunct to language study. Similarly, Akyel and Yelcin (1990: 175) observed that students exposed to literature in order to achieve an educational and cultural goal as well as stimulate their creative and literary imagination and develop their literary competence.

This dual purpose of literary studies has implications for methods and instructional practices in literature teaching. Pedagogic approaches and trends in the teaching of literature vary and continue to change. For instance, Bean and Mori (2003:633) in reference to studies in the United States, reported that in some schools, instructions were teacher-centered as they guided students into predetermined and intertextual and personal connections with literature. But in some other schools, teachers adopted reader-response approach. In another stance, Elliot (1990:191) advocated that teachers should create conditions under which students could develop genuine response to literary texts asserting that literature could only be understood if the student develops literary competence. Williams (1990) contended that literature teaching should be concerned with enabling students to respond to literature, what he described as 'response sophistication' (originality of interpretation). Besides, Uwaifo (1979) observed that prose literature inclination in Nigeria, is primarily characterized by students reading silently followed by reading aloud and answering questions raised by the teacher in the end.

Literature teaching in second language situations could be said to reflect these broad pedagogic orientations. Literature teaching is considered as an adjunct to language study and in this sense much of literature lesson time is spent on explication of language. Another variant perceives literature as a body of knowledge and facts which the teacher gathers and transmits to the students (teacher-centered approach). In addition, the reader-response approach which emphasizes the need for students to experience literature individually and later as a group and community of readers, places 
premium on students responding to what they had read. The students must have a close engagement with the text and not rehearsing the ideas, views of teachers and other literary critics. Beyond these approaches so far discussed, there are lots of instructional practices that teachers adopt in teaching literature in its various aspects or genres.

Instructional practices of teachers are usually reflected in the methods, techniques and activities of teachers and students during lessons. Methods generally refer to the overall manner in which the teacher carries out the process of teaching and learning. Astil (1987) described a teaching method as a set of patterns of interaction either between the teachers and learners or between learners and learning experiences intended to lead to a change in learner behaviour otherwise described as learning outcomes. Strategy refers to a device or technique the teacher uses to implement the method. It may be in verbal or activity form. It may involve questioning, watching and describing or doing something.

Though there are almost as many instructional practices in literature as there are many teachers, they have not translated into satisfactory teaching and student performance. There is still the need to improve instructional systems in order to enhance the quality of learning. School examinations in Nigeria both internal and external have shown a persistent decline in students' performance in virtually all the subjects including English and literature at all levels of the education system. This unpleasant trend has triggered off concerns and doubts about the quality of education generally in the country and in particular secondary education. The low performance of students at the secondary level has implications for students' access to tertiary education and their career aspirations. For instance while a credit pass in English is a general requirement for access to tertiary education, a credit pass in literature is required in such disciplines as English, Law and Mass Communication.

Besides, the continued decline of students' performance in literature examinations has been articulated by WAEC Chief Examiners' Reports over the years. For instance, the May/June 1997 Report indicates that candidates performed below expectation, manifest low knowledge of prescribed texts and exhibit poor command of English. It was further noted that the greatest weakness of the candidates is their lack of in-depth knowledge of prescribed texts. Similarly, the 1998 May/June report attributes students' unsatisfactory performance in literature to their failure to read the prescribed texts, over reliance on study guides, poor command of the language, inadequate preparation for the examination, unseriousness of the students as well as unproductive methods of teaching. Subsequent reports (May/June: 2000,2004 and 2007) echo the same weaknesses especially candidates lack of communication skills, poor knowledge of prescribed texts and lack of innovative teaching approaches by teachers.

There is perhaps no question that the observed sources of students' lingering poor performance could be linked to classroom process variables comprising teachers, students, materials, methods, techniques and their interaction in the teaching-learning process. It has been observed that students in almost all the levels of the education system have lost interest in reading. This unwillingness to read has negatively affected their performance in many school subjects including Literature in English. Students' performance in the senior school certificate examination in literature has been persistently poor. They tend to avoid engagement with prescribed texts. Teachers use unproductive methods that encourage transmission of information. There is therefore the need to explore how teachers and students go about the teaching and learning of literature in the classroom. The study therefore investigated teachers' methods, techniques and objectives of teaching literature as well as their perceived effectiveness of the techniques and objectives of teaching in facilitating students' literacy competence.

\subsection{Research questions}

Three questions were addressed in the study and they are:

1. What methods do teachers adopt in prose literature-in-English lessons and the perceived effectiveness of the techniques used?

2. What classroom activities do students engage in and the objectives of teaching prose literature-in-English teachers should address?

3. To what extent do teachers believe in student-identified difficulties of studying prose literature-in-English?

\section{Methodology}

The descriptive survey research design was adopted in the study. The population for the study comprises all SS II teachers of Literature-in-English in Owerri Metropolis. The purposive sampling technique, based on availability of qualified literature teachers, was used to select 85 secondary schools from Owerri. In all, 246 SS I and SS II teachers comprising 107 males and 139 females participated in the study. Out of the 246 teachers, 15 were purposely selected for classroom observation. The criteria for selection of teachers for observation were professional qualification and at least 3 years teaching experience. The teachers also had at least ten students in their literature class and were willing to participate in the study.

Two instruments were used in the study: Teachers' Questionnaire and classroom observation schedule for prose literature in English. The teachers' questionnaire was entitled Questionnaire on teachers' methods techniques and objectives of teaching prose literature in English (QTMTOPL). It was a 39-item questionnaire of the modified likert type with three scales in response format of great extent, little extent and no extent, and scored 3, 2 and 1 respectively. The questionnaire sought information on teachers' demographic factors, the capacity of identified techniques to foster 
students' skill in literary appreciation, the extent which specified activities could ensure students' participation in literature lessons, the extent to which teachers believed they should be concerned with specified objectives in literature. It also required teachers to rate the degree of difficulty identified factors constitute for students in studying prose in literature -in-English. The reliability of the questionnaire was determined using Cronbach's alpha which yielded a coefficient of 0.87 .

The classroom observation schedule was used to map out methods teachers adopt during prose literature lessons as well as the activities teachers and students engage in. The reliability of the observations schedule was ascertained using Scott's formula and a coefficient of 0.73 was obtained. The data collected were analysed using frequency counts and percentages.

\section{Results and Discussion}

The results are presented in the order of the research questions asked in chapter one.

\subsection{Research Question One}

What methods do teachers adopt in prose literature-in-English lessons and the perceived effectiveness of the techniques used?

Results indicate that teachers adopt the following methods: lecture method (28.4\%), reading method (10.9\%) and discussion method (7.3\%). The lecture method is mostly used by teachers and is characterized by such activities as giving background information to students $(8.9 \%)$, summarizing the chapter to be read $(2.8 \%)$, retelling the story $(4.2 \%)$, dictating notes to students and explaining (5.9\%), writing notes on the chalkboard and explaining $(0.8 \%)$ and narrating events in the text read $(5.8 \%)$.

The reading method featured the following activities of teachers; reading aloud and explaining (3.9\%) as well as explaining during students' reading aloud (7.0\%). However, the discussion method was characterized by such teacher activities as: leading class discussion through questions $(2.8 \%)$, complementing students' answers (2.4\%), assigning chapters to be read from home $(1.4 \%)$ and assigning group tasks to students $(1.5 \%)$. Further details of identified methods and teachers' activities are shown in table 1

Table 1. Teachers' methods and associated activities

\begin{tabular}{clll}
\hline Teachers' Activities & Frequency & Percentage & Methods \\
\hline 1. Gives background information & 699 & 8.97 & Lecture \\
2. Summarizes chapter to be read & 225 & 2.89 & Lecture \\
3. Retells the story & 331 & 4.24 & Lecture \\
4. Dictates notes to students and explains & 460 & 5.90 & Lecture \\
5. Copies notes on the chalkboard and explains & 64 & 0.82 & Lecture \\
6. Narrates events & 459 & 5.89 & Lecture \\
7. Reads aloud and explains & 308 & 3.95 & Reading \\
8. Explains students' reading & 550 & 7.06 & Reading \\
9. Leads class discussing text read & 159 & 2.04 & Discussion \\
10. Asks questions (across methods) & 561 & 7.20 & Discussion \\
11. Expands students' answers & 190 & 2.44 & Discussion \\
12. Assigns chapter to be read from home & 110 & 1.41 & 4.25 \\
13. Answers students' questions & 331 & 1.59 & Discussion \\
14. Assigns group tasks to students & 124 & 3.21 & 61.86 \\
15. Confusion & 250 & 4821 & \\
\hline
\end{tabular}

Results reveal that teachers employ: questioning (7.2\%), oral reading $(6.9 \%)$, silent reading $(0.6 \%)$, scanning $(1.9 \%)$ and discussion techniques $(4.4 \%)$ in teaching literature.

Findings indicate that teachers ranked the perceived effectiveness of the used techniques in this order: questioning $154(62.6 \%)$, debating $125(50.8 \%)$, chapter/paragraph summary 111(45.1\%). The least effective techniques were: use of real objects $177(71.9 \%)$ and loud reading $162(65.8 \%)$. Further details are given in table 2 


\begin{tabular}{llllll} 
IJELS 4(3): $\mathbf{5 4 - 6 1 , 2 0 1 6}$ & & & \\
\hline
\end{tabular}

\subsection{Research Question Two}

What classroom activities do students engage in and the objectives of teaching prose literature-in-English teachers should address?

Results of classroom observation indicate that students engage mostly in these activities: reading aloud (6.9\%), answering questions orally (6.5\%) and copying notes (5.4\%). Further details of students' activities are shown in Table 3

Table 3. Students' activities during prose literature lessons

\begin{tabular}{cll}
\hline Students' Activities & Frequency & Percentage \\
\hline 1. Read silently & 52 & 0.67 \\
2. Read aloud & 541 & 6.94 \\
3. Listen to teacher's reading and explanation & 316 & 4.06 \\
4. Contribute to discussion & 189 & 2.43 \\
5. Answer questions (orally) & 514 & 6.60 \\
6. Copy notes & 427 & 5.48 \\
7. Answer questions (in writing) & 166 & 2.13 \\
8. Retell the story & 190 & 2.43 \\
9. Give summary of chapters & 28 & 0.36 \\
10. Write character sketches & 29 & 0.37 \\
11. Dramatise the story & 40 & 0.51 \\
12. Scan for information from the text & 153 & 1.96 \\
13. Ask questions & 317 & 4.07 \\
14. Discuss in groups & 8 & 0.10 \\
Sub - Total & 2970 & 38.11 \\
Grand Total. Tables land 3 & 7791 & 99.97
\end{tabular}

Findings show that the following objectives should be of concern to teachers: assisting students to develop their critical faculties and analytical skills 200(81\%), enabling students to develop the skill for literary appreciation 198(80.4\%) enabling students to develop ability for extensive and pleasurable reading $187(76 \%)$ and assisting students to develop their language skills 155(63\%). Further details are given in Table 4. 
Table 4. The extent to which teachers should be concerned with teaching objectives of prose literature $(N=246)$

\begin{tabular}{lllllll}
\hline Techniques & \multicolumn{2}{l}{ Great extent } & \multicolumn{2}{l}{ Little extent } & \multicolumn{2}{l}{ No extent } \\
\cline { 2 - 7 } & No & $\%$ & No & $\%$ & No & $\%$ \\
\hline 1. $\begin{array}{l}\text { Helping students develop their language } \\
\text { skills }\end{array}$ & 155 & 63 & 32 & 13 & 56 & 23.9 \\
2. $\begin{array}{l}\text { Helping students explore the world } \\
\text { around them }\end{array}$ & 100 & 40.6 & 86 & 34.9 & 60 & 24.3 \\
3. $\begin{array}{l}\text { Helping students develop the skills for } \\
\text { literary appreciation }\end{array}$ & 198 & 80.4 & 30 & 12.1 & 18 & 7.3 \\
4. $\begin{array}{l}\text { Helping students understand themselves } \\
\text { and the human condition }\end{array}$ & 102 & 41.4 & 100 & 40.6 & 44 & 17.8 \\
5. $\begin{array}{l}\text { Helping students develop ability for } \\
\text { extensive and pleasurable reading }\end{array}$ & 187 & 76 & 13 & 5.2 & 46 & 18.6 \\
6. $\begin{array}{l}\text { Helping students develop their critical } \\
\text { faculties and analytical skills }\end{array}$ & 200 & 81.3 & 46 & 18.6 & 0 & 0 \\
7. $\begin{array}{l}\text { Acquaint students with their literary and } \\
\text { cultural heritage }\end{array}$ & 151 & 61.3 & 60 & 24.3 & 35 & 14.2 \\
8. $\begin{array}{l}\text { Helping students to read independently } \\
\text { especially in other subject areas }\end{array}$ & 93 & 37.8 & 108 & 43.9 & 45 & 18.2 \\
9. Helping students to pass their literary & 113 & 45.9 & 67 & 27.2 & 66 & 26.8 \\
$\begin{array}{l}\text { exams } \\
\text { 10. Helping students to cultivate good } \\
\text { reading habits }\end{array}$ & 70 & 28.4 & 99 & 40.2 & 77 & 31.3 \\
11. Helping students to develop skills in \\
$\begin{array}{l}\text { reading and understanding any literary } \\
\text { text within their level }\end{array}$ & 152 & 61.7 & 83 & 33.7 & 11 & 4.4 \\
\hline
\end{tabular}

\subsection{Research Question Three}

To what extent do teachers believe in student-identified difficulties of studying prose literature-in-English?

Results indicate that students' difficulties in studying prose literature are associated with these factors: students' unwillingness to read prescribed texts $118(47.9 \%)$, poor language ability $112(45.5 \%)$, and lack of interest and motivation 110(44.7\%). More details are given in table 5

Table 5. The extent to which teachers believe identified factors present difficulty to students in studying prose literature

\begin{tabular}{|c|c|c|c|c|c|c|}
\hline \multirow[t]{2}{*}{ Techniques } & \multicolumn{2}{|c|}{ Great extent } & \multicolumn{2}{|c|}{ Little extent } & \multicolumn{2}{|c|}{ No extent } \\
\hline & No & $\%$ & No & $\%$ & No & $\%$ \\
\hline 1. Poor language ability & 112 & 45.5 & 75 & 30.4 & 59 & 23.9 \\
\hline 2. Inability to buy the texts & 9 & 3.6 & 52 & 21.1 & 185 & 75.2 \\
\hline 3. Lack of interest and motivation & 110 & 44.7 & 50 & 20.3 & 86 & 34.9 \\
\hline 4. Difficulty level of the prescribed texts & 1.6 & 43 & 67 & 27.2 & 73 & 29.6 \\
\hline 5. Inability to recall what is read & 98 & 39.8 & 42 & 17 & 106 & 43 \\
\hline 6. Unwillingness to read the texts & 118 & 47.9 & 20 & 8.1 & 108 & 43.9 \\
\hline 7. Teachers' poor method of teaching & 17 & 6.9 & 60 & 24.3 & 169 & 68.6 \\
\hline
\end{tabular}

\section{Discussion}

As indicated by the results, three methods were prominently in use by teachers: lecture, reading and discussion methods. These methods could be related to three models of teaching literature described by Carter and Long (1991) cited in Savvidou (2004) made up of cultural, language and personal growth models. The cultural model represents what is also known as the traditional approach and emphasizes an exploration of the social, political, literary and historical context of the text. In order to give effect to these dimensions of literary study, teachers mostly employ lecture or transmission method. Literature is thus perceived as a body of received knowledge to be learnt through largely the 
lecture mode (Elliot, 1990). This method is teacher-centered, imposes meaning of texts on the student, discourages students' personal engagement with the text, encourages use of 'short notes and study guide as well as inhibits students' personal response to the text. In Nigeria, the use of the lecture method seem to have persisted for too long due probably to teachers' attitude to change, inability of students to purchase prescribed texts and students' unwillingness to read.

The language model of teaching literature emphasizes the teaching of literature for the purpose of developing language skills. The teacher uses literature to exemplify specific language features. Dominant activities include, reading aloud and silently, treatment of new vocabulary, figures of speech, summarizing and answering comprehension questions. This method of teaching literature was described by Uwaifo (1979) as the 'bring out your books and read' approach. It was observed that in most schools, prose teaching began with silent reading and vocal reading in turn followed.

Besides, the personal growth model aims at transmission of knowledge and the development of language skills. Learners are encouraged to express their feelings and views and make connections between their personal, cultural experiences and those contained in the text. Teachers tend to achieve these objectives by combining reading and discussion or lecture, reading and discussion methods. However, such discussions are led by the teacher and tend to reflect an indirect way of transmitting teachers' ideas, feelings and opinions.

Current developments in literary studies appear to be in favour of developing students' personal response to literature. This is what Elliot (1990) descried as literary competence; and Williams (1990) tagged response sophistication. As Elliot remarked, literature can only be understood if the students develop literary competence and that the fundamental ability of a good reader of literature is the ability to generalize from the given text to other aspects of the literary genre or personal and social implications outside literature. Moreover, Bean and Moni (2003) citing (Agee, 2000, Langer, 2001) remarked that various methods are applied in the United States including: discussion, transmission and readerresponse. There is no doubt that teachers should identify with current practices which encourage students' close engagement with texts and personal response to literature as pathways to the development of literary competence.

In addition, it is more likely that a combination of methods or approaches would bring about a more effective teaching and learning of literature. Abraham (2010) advocates an integrated and communicative approach in which literature is taught through language. In this method, literature is taught by creating awareness of linguistic possibilities and sensibility. It involves an emphasis on the linguistic and stylistic aspects of literary work by showing how words and sentences are constructed in order to convey the author's message. Thus learners are made aware of how language is used to communicate messages in memorable ways. Other approaches proposed by Rashid, Vethamani and Rahman (2010) include paraphrastic, information-based, personal-response and moral-philosophical approaches. The present traditional method and associated strategies prevalent in Nigerian classroom would not produce students who could respond to and appreciate literature.

The techniques teachers adopt in teaching literature (questioning, oral reading, silent reading, discussion and scanning) seem to be closely linked with the methods. Usually, teachers ask questions especially at the end of the lecture or transmission method to test the extent to which learners comprehend the body of facts communicated to them. A few of such questions are asked in the course of the lecture to ensure that learners are carried along. Silent and loud reading provide some form of activities to learners who otherwise would have remained passive throughout the lesson period. Reading remains a dominant method and activity where the teacher prefers to present the lesson by reading and explaining as well as giving a summary of what was read. Discussion is adopted in sharing information on what was read. Discussion is guided through teacher directed questions. At times students scan for information to support their ideas or answers.

Though reading can at best enable students know and understand the story line it would not receive the most emphasis. Similarly, questions encourage acquisition of knowledge and understanding of content as well as the development of analysis and synthesis and indeed critical appraisal of texts. Teachers should ask high probing questions.

In a study by Rashid, Vethamann and Rahman (2010) the strategies (techniques) used by teachers were closely linked to the approaches. For instance, the language based approach was characterized by three strategies: guiding students to infer meanings from clues in the text, guiding students to read between lines, generate language practice using the text. For information based approach, the following strategies featured most: explain the main content of the text to the class, guide students to identify and read informative extracts from the story, provide students with the background information and ask questions to check students' knowledge in what they have read. Similarly, the personal response approach was characterized by these strategies: guide students to relate the theme to personal experiences, ask students to compare the text to any text they have read, elicit students' response to a text and encourage students to express feeling towards the issues raised in the text. Perhaps it is reasonable and logical to infer that a combination of approaches and their associated techniques and activities would serve the purpose of literary studies which is primarily the development of literary competence and personal response to literature.

The result further revealed that teachers are concerned with the following objectives of teaching literature: development of students' critical faculties and analytical skills, development of students' literary appreciation skill, extensive and pleasurable reading as well as language skills. These objectives are similar to those identified by Akyel and Yalcin (1990) which teachers in their study fostered. The goals were summarized as the accomplishment of educational and cultural objectives and the development of literary competence. Similarly, Rashid, Vethamani and Rahman (2010:88) 
highlight these objectives of teaching literature: inculcation of reading habits, enrichment of vocabulary and language content, enhancement of thinking skills, promotion of cultural understanding, improvement of language proficiency and development of aesthetic appreciation. Furthermore, Carla (2011) favours the integration of literature as an essential part of foreign language teaching due to its enormous potential in developing not only the students' linguistic skills but also the ability to understand other cultures and imagine other ways of life.

It appears that the objectives of teaching literature are almost the same in many countries. However, what seems different are the methods and strategies for realizing these objectives. The methods, strategies and classroom activities of teachers and students vary. While in some countries, there is a change towards methods that emphasize personal engagement and response to literature, some other countries still rely on the transmission or information based approach to teaching literature. In Nigeria, the teaching of literature is mostly practised through the traditional approach of lecture, in which the teacher provides what he/she thinks students should know about the text. The situation is worsened by the fact that most students do not possess the prescribed literature texts. They rely on study guides and teacher's notes. Hence, there is little engagement of students with the actual texts. This makes it difficult for students to experience the text and make a personal response. This in turn hinders the development of ability to appreciate literature and literary competence.

The primary access to literature is reading. Teachers' responses show that students manifest unwilling disposition to reading the prescribed tests. They also demonstrate inability to read and understand. The reluctance to read has direct bearing with inability to possess prescribed tests. Even if the willingness to read exists, the absence of the text renders it impossible to actualize. Besides, when people read and do not comprehend, the motivation to read further is hampered. Students in their apparent frustration search for alternatives to reading the actual text. These they find in such materials as study guides and teacher's notes. Teachers on their own part resort to the lecture method and use of oral reading and summarizing what is read in class. The approach at best could enable students pass examinations but would not enable them develop literary competence and aesthetic appreciation of literature.

The inability of students to read the actual texts and respond to them appropriately has been observed by the WAEC Chief Examiner's reports on prose literature-in-English (2012 and 2014) which stated that candidates showed no remarkable improvement in their performance as in the previous years. It further noted that most of the answers given by the candidates were irrelevant because they merely narrated stories. It was also revealed that the vague knowledge of texts exhibited by the students was acquired through abridged texts or keynotes. All these indicate that many students did not read the actual texts.

\section{Conclusion and Recommendations}

The purpose of studying literature in any country appears to be a key factor in determining how it is taught and relevant classroom activities of teachers and students. In Nigeria, literature study serves the purpose of language development, cultural transmission, personal development and literary appreciation. Literature and language are inextricably interwoven. A single approach or method would be inadequate to teach literature effectively.

The results indicate that teachers predominantly adopt the transmission methods (lecture, read and explain) using these classroom activities: oral reading and explaining, giving notes, and story retelling. Besides, teachers rated questioning, debating/discussion and summarizing as the most effective techniques. They also identified development of students' critical faculties, analytical skills, literary competence and reading skills as the objectives prose literature teachers should address. Moreover, unwillingness to read, low language proficiency, lack of interest and motivation for reading were identified as students' difficulties in studying prose in literature.

It is perhaps right to infer that teachers are not creative and innovative enough in their methods and techniques to enable students' access prose in literature. It is therefore recommended that teachers should use evidence based methods, techniques and integrated approaches in facilitating the study of prose in literature. They should be encouraged to attend seminars and conferences and be involved in teaching and learning oriented researches.

\section{References}

Abraham, A. P. (2010). ELT Research Article: Teaching literature through language: Some considerations. ELT Weekly Powers by Word press and Manifest, 1-9.

Akyel, A. and Jalcin, E. (1990). Literature in the EFL Class: a study of goal-achievement incongruence. ELT Journal, 44(3), 174-180.

Astil, P.N. (1987). Learner-Teacher Interaction and Human Learning in School, In Ezewu, E.E. (Ed) Social Psychological Factors of Human Learning in School (pp. 102 - 119). Onitsha Leadway Books Ltd.

Bean, T. W. and Moni, K. (2003). Developing Students' Critical Literacy: Exploring identity construction in young adult fiction. Journal of Adolescent and Adult Literacy 46(8), 638 - 648.

Carla, C. K. (2011). Poetry in foreign language teaching: aspects of a major challenge Proceedings of ICERRI 2011conference; 14th - 16th November, Madrid, Spain Retrieved December 22, 2014 from http://hep.lub.lu/record/2278641/file/2278653.pdf. 
Dietz, D. T. (1978). An alternative approach to the Teaching of Literature. ADFL Bulletin 10(1), 39-42.

Elliot, R. (1990). Encouraging reader-response to teach literature in ESL situations. ELT Journal 44(3), 191-198.

Rashid, R. A, Vethamani, M. E., and Rahman, S. B. A. (2010). Approaches Employed by Teachers in Teaching Literature to less proficient students in Form 1 and Form 2. English Language Teaching 3(4), 87-99.

Savvidou, C. (2004). An integrated approach to teaching literature in the EFL classroom. The Internet TESL Journal, X (12)1-6.

Uwaifo, R. O. (1979). The Teaching of prose in Nigerian secondary schools, In Ebo Ubahakwe (Ed) The teaching of English studies readings for colleges and universities (pp. 195-216). Ibadan University Press.

The West African Examination Council (WAEC), (May/June, 1997). Senior School Certificate Examination Chief Examiners' Report (pp. 37 - 40), Yaba Lagos Test Development Division.

The West African Examination Council (WAEC), West African Senior School Certificate Examination (May/June, 1998). Chief Examiners' Report (pp. 43 - 50), Yaba Lagos Test Development Division.

The West African Examination Council (WAEC), West African Senior School Certificate Examination (May/June 2000). Chief Examiners’ Report (pp. 27 - 31) Yaba - Lagos.

The West African Examination Council (WAEC) West African Senior School Certificate Examination (May/June 2004) Chief Examiners' Report, Yaba - Lagos.

The West African Examination Council, West African Senior School Certificate Examination (May/June 2007). pp. 50 -55 , Yaba - Lagos.

The West African Examination Council (WAEC) West African Senior School Certificate Examination (May/June 2012). pp. 35 - 42, Yaba - Lagos.

The West African Examination Council (WAEC) West African Senior School Certificate Examination (May/June 2014). Yaba - Lagos.

Williams, D. (1990). English Language Teaching: An Integrated Approach. Ibadan Spectrum Books Ltd. 